\title{
Paideusis
}

\section{Values and Values Education: An Introduction (David Carr and John Haldane)}

\section{Richard Barrett}

Volume 8, Number 2, 1995

URI: https://id.erudit.org/iderudit/1073258ar

DOI: https://doi.org/10.7202/1073258ar

See table of contents

Publisher(s)

Canadian Philosophy of Education Society

ISSN

0838-4517 (print)

1916-0348 (digital)

Explore this journal

Cite this review

Barrett, R. (1995). Review of [Values and Values Education: An Introduction (David Carr and John Haldane)]. Paideusis, 8(2), 45-46.

https://doi.org/10.7202/1073258ar

(C) Richard Barrett, 1995

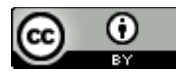

This document is protected by copyright law. Use of the services of Erudit (including reproduction) is subject to its terms and conditions, which can be viewed online.

https://apropos.erudit.org/en/users/policy-on-use/
This article is disseminated and preserved by Érudit.

Érudit is a non-profit inter-university consortium of the Université de Montréal, Université Laval, and the Université du Québec à Montréal. Its mission is to promote and disseminate research.

https://www.erudit.org/en/ 

duction. St. Andrews, Scotland: Centre for Philosophy and Public Affairs, 1993.

This short book consists of two articles, one by each of the authors, together which a preface, an introduction, and a bibliography of suggestions for further reading. The preface is written by W.A. Gatherer, the chair of the Gordon Cook Foundation, an independent charitable organization dedicated to the promotion of values education, which is understood as the fostering of personal, moral, social, and political development. The Foundation commissioned two philosophers to write on the complexities of the issues underlying values education as promoted by teachers. Gatherer says he is confident that the book will serve that purpose well, and that it will, in addition, be a contribution to the literature of educational philosophy.

In the introduction, John Haldane, Director of the Centre for Philosophy and Public Affairs at the University of St. Andrews, explains that the work is addressed to educators, students, and general readers, who, it is hoped, will be stimulated into critical engagement with the issues presented by the authors, and will pursue the suggested reading accordingly.

The first article by Haldane called "The Nature of Values" aims is to dispel the notion that values are nothing more than personal preferences. It begins by pointing out that the ideas explicitly or tacitly adhered to by many who are not philosophically minded are, nevertheless, ideas that stem from the philosophical movements of the last three centuries. This is a good way to incline the reader to what comes next-some sharply-made distinctions between key terms such as type and instance, deontological and consequentialist, and levels of analysis.

After these preliminaries, Haldane explains the saliency of the central question-Are values objective? - by giving a historical account of the fact/value distinction. In his view, it arose out of empiricism when a scientific (mathematical and mechanical) view of reality replaced the Aristotelian world of matter and form, hierarchy and function. This account is interesting, but at times somewhat difficult for the novice. It does, however, leave a clear impression of the empiricist notion that values are different from facts, and so explains why it is easy to suppose that values are subjective. It also makes the important connection between the empiricist movement and utilitarianism.

After the historical background, Haldane attempts to restore the credibility of the objectivity of values. The main point is that

even 'subjectivists' tend to be 'objectivists,' about the values of evidential weight, rational cogency, argumentative rigour, coherence, intelligibility, and truth. They do not suppose that the determination to be guided in one's thought by such values is no more than a matter of preferences. (p. 18)

In this, one might find it bracing that procedures of rationality in argument and dispute are found to be indispensable. Yet, the sudden introduction of procedures, as contrasted with the substance of moral and other value judgments, could easily strike the reader as contrived.

The article ends with a list of familiar objections to the claim that values are objective, with replies of just a sentence or two to each. These are of value only as indicating points for further discussion. 
The second article entitled "Problems of Values Education" is by David Carr of Herriot-Watt University. Like Haldane's article, it begins very well. The educational significance of the whole book is indicated when Carr states that education includes the transmission of values as part of rational reflection on the goals and purposes of human life. How values are transmitted will depend on what their nature is understood to be.

The distinction between intrinsic and extrinsic value is crucial in Carr's discussion. He associates extrinsic value with utilitarianism, and with much current thinking on social ills and the role of the schools in overcoming them. For Carr, the current thinking is superficial, and he holds that moral improvement and the enhancement of civilised human life demand the development of virtues that are good in themselves. These virtues might include honesty, selfcontrol, and courage, and they are of benefit to the possessor irrespective of societal consequences; virtue is its own reward.

The transmission of what is intrinsically worthwhile and valuable is familiar to us as an educational philosophy known as "traditionalism," says Carr. There is, then, no separate question of values education, for education as such necessitates the passing on of cultural and other values that are reflected in "the best that has been thought and written in the world"-a project which, in turn, needs no justification beyond itself.

This concept of education as the communication of things of intrinsic worth is presented well by Carr, and is, I think, accessible to those who may in these utilitarian times have lost most of their memories of such ideas, and who will, I hope, find it engagingly elevated. At the same time, Carr gives a careful survey of objections to traditionalism. The objections include the concerns about authority and paternalism, the progressive ideas from Rousseau and Dewey, and radical critiques. Carr explains how all the objections involve questioning whether the values of the traditionalists are absolute or objective.

Liberal education is seen as a middle way between traditionalism and its critics because it is an initiation, not into fixed or received orthodoxies, but into areas of enquiry which possess their own procedures for revising established notions and generating new lines of thought. Values education, then, becomes the learning of disciplined ways of enquiring into the good and true.

The concluding section of Carr's article is the most demanding on the reader. He explains that liberalism offers no clear way to deal with values, other than to ignore them, and that in educational contexts, many confusions have arisen because of a lack of understanding of important distinctions, such as between scepticism, tolerance of diversity, neutrality and agnosticism, and between certainty and objectivity. Carr believes, however, that there can be no education in values unless they are "viewed as potentially true or false in some substantial or objective sense" (p. 32).

In terms of the Foundation's aims for the book, both authors manage to articulate, in a short space, the complexities of the underlying issues of values education. They also situate the issues in the context of movements and tensions in philosophy and education. While probably containing little that is original, the work is a useful contribution to the literature of philosophy of education, and could be recommended for any scholar or general reader interested in the topic. 